\title{
Matthew 1:1-17: Cultural Subiugation of Women in Shona Communities in Zimbabwe: A Hermeneutical Study
}

\section{Lovejoy Chabata}

https://orcid.org/0000-0001-8596-9694

Africa University, Mutare, Zimbabwe

Chabatal@africau.edu

\section{Abstract}

The space accorded women in the genealogy of Jesus Christ glowingly typifies the subordination of women in African communities generally. Appositionally, 42 men against five women are mentioned in the family tree of Jesus in Matthew 1:1-17. The domination of males in the lineage of Christ rebuts the theology of Jesus as "the seed of the woman" (Compton 2018, 1; Hamilton 2006, 30; Luther $1958,192)$. The relegation of women to a silhouetted horizon in the ancestral lineage of Jesus typifies the manner in which Shona traditions in Zimbabwe peripheralise women in issues of property and inheritance (Kambarami 2006, 7; Ncube 1996, 9; Riphenburg 1997, 33). In this article, I interrogate the status of women in the Matthean lineage of Jesus in light of patriarchal suppression of women in inheritance and property rights in Zimbabwe.

Keywords: Matthew 1:1-17; women's rights; patriarchy; inheritance laws; women empowerment

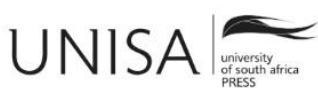




\section{Introduction}

In a typical patriarchal manner, the genealogy of Jesus in Matthew 1:1-17 relegates women to the fringes of human history. Naseri-Mutiti Naseri $(2011,1)$ argues that Matthew's genealogy is modelled on Old Testament genealogy, in which female names are generally rare. Apart from Mary, the mother of Jesus, only four women against a list of 42 men are mentioned. While much of the research on Matthew 1:1-17 has concentrated on the relevance, the character, female status, origin and trades of the four women mentioned in the pericope, in this article (in addition to adding a voice on the relevance of the four Old Testament women to the Jesus narrative), I argue that, apart from skewed patriarchal prejudice, women deserved a better place in the genealogy of Jesus. I aver that the author of Matthew 1:1-17 treats women as inferior and secondclass citizens in a pattern homologous to the Shona custom in Zimbabwe, where women are not entitled to inheritance rights as they are treated as mere objects of human reproduction (Cheater 1986, 65; Makaudze 2015, 11; Riphenburg 1997, 34). Kambarami $(2006,7)$ observes that in Shona culture, by virtue of the payment of lobola (bride price) by the man into the family of the woman, children belong to the father and inherit the father's surname, totem and citizenship. This article, therefore, interrogates the rank accorded women relative to men in the genealogy of Jesus, with the view to reconstructing a befitting place of the former in the story of Jesus. As a corollary, the article proffers a progressive, reformed and transformative way of treating women as co-equal and co-partners with men in the making of human history and posterity.

\section{Methodology}

In this article, the method undergirding my hermeneutical praxis is socio-historical criticism. Ehrman $(2016,182)$ posits that socio-historical criticism focuses on how biblical texts speak to a broader socio-political and cultural milieu, regardless of whether the study is dealing with ancient societies, medieval or present-day societies. According to Slade $(2020,2)$, the socio-historical study of religion brings together the aims, philosophies and methodologies of historical science with those of the social and cultural sciences, including anthropology, sociology, psychology and religious history. In essence, socio-historical criticism invokes and involves interpretation of biblical texts and religious phenomena through the lens of social/historical contexts and in the process makes the context surrounding religion, the primary subject of study. Thus, the sociohistorical method will capacitate me to investigate the customs, traditions, religious practices, culture, society and social norms as well as the family tree of Jesus - and specifically the role of women in the configuration of that family tree.

\section{Reasons for Choice of Socio-historical Method}

The socio-historical critical method has been chosen for this study due to the following reasons:

i. The method is syncretistic in nature, in that it allows a convergence of diverse approaches to the study of religious phenomena. In this article, the method's 
nuanced form makes it easier for me to mix social scientific trajectories, such as anthropology and sociology, with historical-critical approaches such as source criticism, form criticism, redaction criticism, textual criticism and literary criticism.

ii. The method allows me to analyse the marginalisation of women in Matthew's genealogy of Jesus from cultural, political and religious dimensions by drawing on proximities between the text and the Shona communal context.

iii. The method creates flexibility and analytical elasticity when it comes to the study of patriarchal behaviours of the Matthean community, in comparison with those of the Zimbabwean Shona communities.

iv. As a starting point, I shall carry out an exegesis of Matthew 1:1-17 from a historical-critical perspective in order to unpack the worlds behind and inside the text. Lines of connectivity will then be explored between the world behind the text and the Zimbabwean Shona worldview on the place of women in issues of inheritance rights. The role of women as key players in issues of social reproduction, economic and moral development, will then be discussed as a vindication of the need to reconstruct and properly define the position of women in the making of human history. In the final stage, the article posits that as "the seed of the woman" Jesus' mission to the world should be seen as empowering and liberating for the women, whose seed is Jesus.

\section{Exegetical Study of Matthew 1:1-17}

\section{Authorship of the Text}

There is general consensus among scholars that the text was written by Matthew, a former tax collector, also called Levi. Guzik (2008) notes that when Matthew followed Jesus, he abandoned everything else but not his pen and paper, as he used his literary skills to become the first man ever to compile an account of the teaching of Jesus. Guzik (2008) argues that as a former tax collector, Matthew was qualified to write an account of Jesus' life and teachings; a tax collector of that time was expected to know Greek. Guzik (2008) further suggests that due to his writing capabilities, Matthew most likely acted as the "recorder" among the disciples of Jesus, taking notes of his teaching. Benson (1839) contends that the opening words of the text, Bí $\beta \lambda$ os (the book) for "This is the book," show that the writer must have been someone familiar with the Hebrew literary custom, who could be none other than Matthew, the former tax collector. Brown (1882) endorses the authorship of the text by Matthew, the former publican or tax collector who resided in Capernaum on the western shore of the sea of Galilee. Brown states that all antiquity has been unanimous on the authorship of the text by Matthew, the former tax gatherer. Brown (1882) specifies that all antiquity refers to the genealogy account as the work of Matthew, the publican and apostle.

Meyer (1884-1887) states that Evangelist Matthew adopted, without alteration, the genealogical piece of writing Bíp $\lambda_{0} \varsigma$ from Genesis 2:4, Genesis 5:1, Genesis 6:9 and 
Genesis 11:10. Matthew adopted both the content and title of the genealogy from Hebrew genealogical philology in the Old Testament. Meyer's finding is corroborated by Ellicott (1897), who observes that the opening words of the text

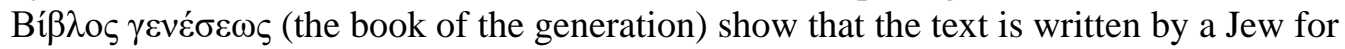
Jewish readers. Ellicott (1897) further argues that the text bears Hebrew genealogical literary formula traceable to Genesis 5:1 and Genesis 37:2. Early New Testament scholars argue that Matthew, the converted tax collector who was hated by his fellow Jews for serving in the government of their colonisers, now wanted to atone for his former betrayal by pointing out that Jesus belonged to the chosen nation of Israel, the descendant of Abraham who was going to continue in the suzerainty of David.

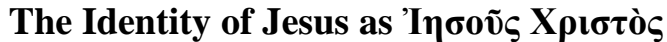

Nicoll (1897), in the Expositor's Greek Testament, states that the use of Christ in 'Inбoṽ

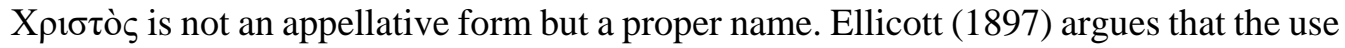
of the proper name was absolutely necessary against a background of many other people bearing the same name, such as Jesus the son of Sirach and a Jesus surnamed Justus, mentioned in Colossians 4:11. Pilate's reference to "Jesus which is called Christ" in Matthew 27:17 connotes existence of many other people bearing the name "Jesus." It was necessary for Matthew to state that this particular genealogy was that of Jesus, the awaited Messiah of the Jews, the true Anointed of the Lord. The designation 'Inooũs

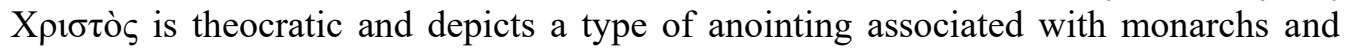
priestly offices.

Meyer (1887) contends that the title Xpıбtò sis conferred on Jesus in recognition of his identity as the king of David's race, that the Christ's coming, according to the predictions of the prophets, was more ardently looked for. It was expected of the Christ or Messiah to raise the nation of Israel to its theocratic consummation, to restore the kingdom of Israel to its sublime power and glory. The potency of the Messiah would eventually extend and spread to the Gentile worlds in order for him to bring to ultimate consummation the true spiritual government of God. Xpıбтò eventually assumed the status of a nomen proprium in the Apostolic age and appears universally in the epistles and in Acts as the universal name of Jesus. Thus, according to BDAG of Bauer et al. (2000, 1091), the Christ of Matthew is the fulfiller of the Israelite expectation of a deliverer, the Anointed One, the Messiah. Matthew does not use the designation

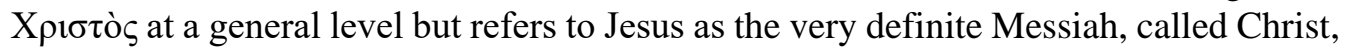
not as a title but a proper and personal name.

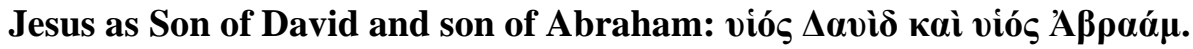

Bauer et al. $(2000,1025)$ state that the reference to Jesus as the son of David (vioṽ $\Delta \alpha v i \delta$ ) means that Jesus is a male child who is in a kinship relationship, either biologically or by legal entitlement. Matthew here fulfils his desire to present Jesus as the descendant or offspring of the legendary King David. Consistent with prophecy, Jesus as the Messiah was expected to descend from the house of David. Matthew's 
genealogy of Jesus traces his origins to David because Jews would not receive a Messiah who would emerge from a different family tree.

Matthew's starting with David and not with Abraham has nothing to do with rank or age, but he is cognisant of the need for the fulfilment of prophecy of the birth of the Messiah in the house of David. Matthew is aware of the expectations and priorities of his Jewish audience. Fulfilment of Messianic prophecy comes to the forefront of everything. Thus, the urge and compulsion to introduce the fulfiller of expectation according to prophecy, necessitate the "scissor kick" introduction of Jesus as first and foremost, the son of David (Jeremiah 23:5; Psalm 132:10-11). The Cambridge Bible for Schools and Colleges states that Matthew's genealogy had to provide an answer to the question which would be asked by every Jew, "Is he of the house of David?" for by no other name was the Messiah more frequently spoken of by both Jews and foreigners. The Jewish Talmud also designated the Messiah as the Son of David, hence, Matthew's genealogy of Jesus needed to appeal to both Pharisees and Sadducees who constituted the Sanhedrin. Jesus is also introduced as the Son of Abraham in fulfilment of God's promises to Abraham that salvation of all nations would ensue from his loins.

\section{Matthew's Society, Customs, Gender Norms and Values}

An analytical study of the gender, social norms, customs and epistemological patterns of the Israelites will help in understanding the reasons undergirding their attitudes towards women. It will also open up windows of comparison with the Shona gender approaches.

\section{Inside Matthean Society}

Our text, Matthew 1:1-17, is situated in a patriarchal social setting in which maleness, masculinity, femaleness and femininity constitute phenomenal gender stereotypes of far-reaching implications in matters of equity and parity between men and women. Descent in Matthew's society is traced through males. I have noted that in the Jewish society, women are not mentioned in the genealogy to such an extent that Matthew's mentioning of Mary and the four women from the Old Testament, Tamar, Rahab, Ruth and Bathsheba is viewed as anomalous and untypical of Jewish genealogies (Barclay 1975, 17; Naseri-Mutiti Naseri 2011, 1; Padfield 2020, 9). Padfield (2020, 9) states that it is not normal to find names of women in Jewish pedigrees at all. The Jewish woman had no legal rights, was not regarded as a person but a thing, as the possession of her father and husband, at his disposal to do with as he liked. Barclay $(1975,18)$ further states that the genealogy of Jesus in Matthew is located in a society where the man is destined for greatness and superiority over women. Brown $(1993,65)$ argues that Jewish genealogies mainly functioned to undergird social status, especially for the offices of king and priest where lineage is important. In such a society, where royalty and priesthood were status symbols, women were relegated to inferior roles of child bearing. 
Bauckham $(2002,17)$ contends that the appearance of four women from the Hebrew Bible (Tamar, Rahab, Ruth and Bathsheba) in the Matthean genealogy has occasioned much discussion because normally women would not have a place in a patrilineal genealogy. Neyrey $(2003,43)$ opines that the society in which Jesus was born and raised was gender-divided and roles of men and women stereotyped in such a way that men were prepared for public and outdoor responsibilities, while women were raised to assume subordinate indoor chores. Neyrey $(2003,44)$ insinuates that the criteria for honour and praise in the Matthean community delineated roles in which the mention of women in genealogies could not be one. Botha $(2003,508)$ argues that the Matthean genealogy substantiates Jesus' claim to patrilineal titles of leader and king. Botha (2003, 508-509) further observes that patrilineal stereotyped roles of father and son, which mark the beginning and end of the genealogy passage, constitute key motifs throughout the book of Matthew.

To conclude this section, the following characteristics of the Matthean community, as reflected in the genealogy of Jesus, are noteworthy:

i. The Matthean community is a male-dominated society.

ii. Women in a Matthean (Jewish) community do not possess legal rights.

iii. Gender stereotyping is intended to benefit males more than women.

iv. Male children occupy an enviable space of privilege compared to the girl child.

v. Levirate marriage law relegates women to the level of men's property.

vi. Inheritance and property rights are generally elusive to the feminine gender.

vii. Mention of the five women in a list of 42 men is regarded as peculiar to Matthew.

viii. Scholars question why Matthew includes women in the genealogy of Jesus contrary to Jewish custom.

\section{Parallels between Matthean and Shona Communities: Women Rights Issues}

In this section, the article draws parallels between the Matthean and Shona communities on the subject of women's legal, inheritance and property rights.

\section{Matthean and Shona Communities}

A study of the Matthean society in the previous section of this article has revealed that Jewish women in Jesus' time were marginalised due to socially constructed gender stereotypes (Neyrey 2003, 43). Patriarchal societies seem to thrive on similar precepts. Ademiluka $(2018,349)$ contends that, similar to ancient Israel, patriarchy is very much part of African life and is deeply entrenched in the norms, values and customs of the 
continent. Ademiluka $(2018,349)$ further argues that in sub-Saharan Africa, as in Israel, the male is lord over the female and it is the male's will and cultural norms which dominate and legislate. Kambarami (2006, 2) observes that in Shona culture, patriarchal practices shape and perpetuate gender inequality and strip women of any form of control over their sexuality. In a similar trajectory, the power of Hebrew custom over women is exemplified in the story of Tamar, one of the four Old Testament women mentioned in the genealogy of Jesus. Naseri-Mutiti Naseri $(2011,4)$ narrates the heart-renting ordeal of Tamar who, after her husband Er's death, went through an ordeal of sleeping with her husband's younger brother, Onan; and then with the father of her husband, Judah, after he denied her access to his son, Shelah, who was under a legal obligation to replace his two late brothers as Tamar's husband in terms of Hebrew custom. The story, captured in Genesis 38:1-30, graphically affirms how women were used as sex objects and reproduction tools in the Hebrew society. Tamar's alleged promiscuity arises from traditions that muzzle women's rights to self-determination and sustenance, making them depend on men for the basic needs of life. Women are at times denied their sexual rights in the name of keeping widowhood protocols that forbid sexual activities outside a woman's late husband's family. In the case of the Shona, a widow cannot engage in sexual activities until after a year from the date of her husband's death. A widow who sleeps with a man before the expiry of a year after the death of her husband, commits a taboo called kupisira guva (desecration of her husband's grave). Due to lack of or limited access to means of production, most women in Shona communities exchange sex with men for basic needs such as food, clothing and even shelter. Thus, women do not engage in sex outside of marriage because it is just a means of income, but because social structures are not conducive to their full participation in economic production, they resort to sexual activities as a last resort. Hence, prostitution, as I see it in this instance, is a product of unequal access to resources between men and women.

Tamar was of Canaanite descent, having been married to Er, Judah's eldest son. After her husband died, through levirate marriage law, she was mandated to move in with Onan, her late husband's younger brother in order to raise children in the name of Er. Onan had an obligation to raise children with Tamar and continue the inheritance of his deceased brother. Conscious that the children from his conjugation with Tamar would not be legally his, Onan spilled on the ground his male seed by practising coitus interruptus at every sexual encounter with the widow. For his wicked act, God allegedly struck him dead. Tamar had to wait for Judah's youngest son, Shelah, to mature so that she could be inherited by him and make children on her first husband's behalf. After waiting for a long time, she was betrayed by her father-in-law, Judah, who decided not to give Shelah to her, fearing that his youngest son might die like his two late brothers if he moved in with Tamar. After realising that she had been deceived, Tamar beguiled her father-in-law Judah into sleeping with her, after pretending to be a prostitute. Tamar conceived after sleeping with Judah, resulting in the birth of twins Zerah and Perez. When the matter came to light, Judah remorsefully pardoned Tamar and declared her risky scheme as an act of righteousness. 
Perez, one of the twins, is mentioned in the genealogy of Jesus as the ancestor of David.

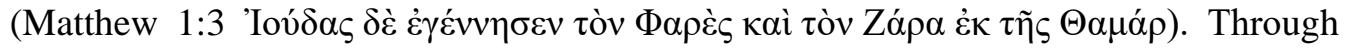
Perez, Tamar is mentioned in the genealogy as an ancestress of Jesus. According to Naseri-Mutiti Naseri $(2011,5)$, scholars use the story of Tamar to raise questions of social responsibility and justice in relation to women. One notices from the story of Tamar how women are helplessly caged and hamstrung in patriarchal customs that muzzle their freedom of choice and personal development. Custom tied Tamar down to Judah's family. After her husband's death, she was subjected to a frustrating relationship with Onan, who only wanted her for sexual gratification but did not want to make children with her. She was obliged to wait for Shelah, her late husband's surviving youngest brother, whom she was denied after the long wait. Judah, Tamar's father-in-law who represents patriarchal authoritarianism, callously trampled on her rights. Despite the odds facing her, Tamar used her own resources to extricate herself from shame by shrewdly tricking her father-in-law into procreating with her. One observes that when an oppressive customary belief is enmeshed in a religion, it renders those on its receiving end helplessly miserable. Such has been the fate of most women in Africa generally, and of Zimbabwean Shona women in particular (Kambarami 2006, 1). Lightfoot-Klein $(1989,47)$ notes that "Custom in Africa is stronger than domination, stronger than the law and even stronger than religion."

The Shona, like the Hebrew community, practise levirate marriages. Mwandayi and Chirongoma $(2020,1)$ argue that the story of Tamar in Genesis 38 is symptomatic of the suffering that women endure under African and Israelite patriarchal hegemony. The Israelite society, herein called Hebrew or Jewish society, like the Shona community, subjects widowed women to a lot of pain and suffering due to oppressive levirate marriage laws. Widows in Shona communities (like Tamar of Israel) are usually suspected of being responsible for the death of the husband; as a result of which they are subjected to gruelling suffering by the surviving relatives of the late husband. Mwandayi and Chirongoma $(2020,6)$ argue that widows in the Shona society often suffer double jeopardy of marginalisation and gender-based discrimination. A similar experience is endured by Jewish women who tend to lose their rights to property and respect in the community as soon as their husbands die. In the Tamar story, Judah sent Tamar packing back to her parents without anything, on the promise that he would call her back after the youngest son Shelah had matured. The law did not permit Tamar to fall in love with any man outside Judah's household. Nolland $(1997,534)$ states that Judah's failure to give Tamar to his third son, Shelah, effectively excluded her from Israel. Through her drastic action of tricking her father-in-law into sleeping with her, Tamar secured her re-inclusion in Israel. Shona widows, in like manner, by remarrying into the late husband's family, redeem and salvage some dignity. Among the Shona, widows who refuse to be inherited patrilineally by brothers of their late husbands, are often abandoned and neglected. Mwandayi and Chirongoma $(2020,7)$ point out that both the Israelite and Shona communities believe in what is called kugara nhaka (Shona for patrilineal wife inheritance). Patrilineal wife inheritance arises from the understanding that a woman marries into an extended family, such that when the man 
who first marries her dies, one of the siblings of her deceased husband is expected to inherit her together with (or as part of) her late husband's property.

At this point, it is expedient that I discuss the mention of Ruth in the genealogy of Jesus. As it is in the Shona community, a widow is expected to remarry her late husband's next of kin. In Israel, the widow's kin who inherits the widow is called a kinsman's redeemer. In the Shona community a special ceremony is held whereby a widow is supposed to hand a gourd of water to the man she chooses to inherit her as wife from among her late husband's siblings. Although her deceased husband's siblings from the whole kinship sit on the mat for her to select a husband, she is usually expected to choose her late brother's immediate younger brother. Where the late husband did not have an immediate sibling, the widow chooses the one nearer to her late husband in the lineage in the extended family kinship. In Ruth 3, in a similar pattern to the Shona system, Ruth was supposed to be redeemed by someone closer to her late husband, Mahlon, but the nuclear family candidate passed his right to Boaz, who was next in line.

According to Naseri-Mutiti Naseri $(2011,9)$, Ruth is mentioned in the genealogy as the woman with whom Boaz, the son of Rahab, fathered Obed, the father of Jesse, the father of David. Obed, the son of Ruth with Boaz, became David's immediate grandfather. The mother of Boaz, Rahab, was also a Gentile. Upon inheriting Mahlon's piece of land and wife, Boaz took over everything that belonged to Mahlon. The same practice happens among the Shona where the man who practises kugara nhaka (inherits the patrilineal wife) assumes responsibility for everything that belonged to the deceased relative. At the time that Naomi and Ruth arrived in Israel from Moab, they did not have any status and could not be recognised at all because they did not have husbands. Naomi and Ruth could only have rights to land via their husbands. This is typical of women's underprivileged status in Shona community. Parpart $(1995,8)$ states that, in Zimbabwe, men continue to have easier access to property and credit than women. Parpart (1995, 9) further observes that during the land resettlement scheme, individual land grants were awarded to men as heads of households. Married women were prevented from owning land apart from their husbands. If a woman got divorced or widowed, she lost the right to the land because it was registered in her husband's name. Parpart $(1995,9)$ further argues that widows were not entrusted with land because the authorities were sceptical about their potential productivity.

Ncube $(1996,5)$ notes that in Zimbabwe there is an entrenched system of customary law of inheritance that completely cuts off widows from inheriting the estates of their late husbands. The customary law of inheritance, Ncube $(1996,5)$ argues, exists on paper as an attempt to address inequities in inheritance legislation because there is a customary law practised by people in their daily lives which completely excludes women from the inheritance process. The court customary law stipulates that in the event of a man's death, there is a single heir to his estate, being his eldest male child; failing male children, the eldest daughter; failing daughters, the eldest male grandson; or failing grandsons, presumably the eldest granddaughter; or on the failure of 
grandchildren, the deceased's eldest brother. The effect of the court customary law was to completely remove widows from the inheritance process. Ncube $(1996,5)$ says: "The net result of this version of customary law has been the complete exclusion of women as wives, mothers and sisters from the inheritance process." One notes that, while the Zimbabwe judiciary system has promulgated new laws that provide for women's access to property acquired intestate in marriage at the death of the husband, traditional practices that discriminate against women have continued to persist unabated in rural Shona communities. Dengu-Zobgo et al. (1994) argue that there continues to be a living customary law that bitingly segregates against women in matters of property inheritance in most Zimbabwean communities, Shona or Ndebele.

Landman and Sibiziwe $(2020,5)$ note that the Zimbabwe government has made attempts to open access to land for women through the National Gender Policy (2013-2017), which aims to address gender inequalities. Landman and Sibiziwe $(2020,6)$ further argue that the National Gender Policy (2013-2017) aims to create equal opportunities between men and women in the following ways:

- Creating platforms for the eradication of gender inequalities and discrimination in all spheres of life and development.

- Affording women access to land through the Land Reform Programme.

- Fostering gender parity models in the distribution of national resources, especially land.

Landman and Sibiziwe (2020,6), citing research carried out by the University of Zimbabwe on the latest statistics on land, observe that women constitute $18 \%$ of land recipients under A1 and $12 \%$ under A2; thus, falling far short of the gender parity model. The insidious influence and effects of patriarchy on women's access to land and property resources in Zimbabwe have continued even in the post-colonial period. As Landman and Sibiziwe $(2020,12,13)$ argue, both Christianity and African Traditional Religion, through the institution of patriarchy, have maintained structures that discriminate against women's access to land and other economic resources.

Heffern $(1912,70)$ opines that the stories of Tamar and Ruth depict Matthew's interest in the admission of Gentiles into the church of the Messiah. Ruth's story is quite intriguing, in that as a Moabite, she was born under a curse. In Deuteronomy 23:3, the God of Israel had commanded that Moabites were permanently shut out of the congregation of the Lord. Ruth's fate-turning choice to align herself with Naomi, and later with Boaz, eventually allied her with the God of Israel. Ruth also ended up having the canonical book of Ruth being named after her.

The other woman mentioned in the genealogy of Jesus is Rahab. She perfectly represents the stigmatisation of single women, both in Israelite and Shona communities, as "prostitutes." Taylor $(2016,2)$ argues: "It's as if 'the prostitute' were her second name." The story of Rahab is captured in Joshua 2. She is introduced as the prostitute 
or sex worker in the city of Jericho who, upon realising the unusual power in the God of the Israelites, played a pivotal role in the downfall of Jericho at the hands of the Israelites. Rahab chose to follow the God of Israel over the gods of Canaan, declaring that Yahweh was "the God in heaven above and on earth beneath" (Joshua 2:11). After her spectacular feat of hiding the Israelite spies, which culminated in the annihilation of the city of Jericho, she married Salmon and together they begat Boaz, who married Ruth, and in turn Boaz became the father of Obed, the father of Jesse, the father of David, from whose house Jesus, the Messiah would emerge. Coote $(1998,596)$ argues that Rahab distinguished herself as an epitome of faith combining with works to produce an accomplished Yahweh worshipper. The stigmatisation of Rahab as a sex worker cannot be isolated from the prejudices that patriarchal systems visit on women generally, and single women particularly. That she pleaded for the security of her father, mother, brothers and sisters, speaks about her sense of responsibility as a caring adult (Joshua $2: 13$ ). Her condition could have been exacerbated by labour conditions in patriarchal societies that discriminate against women in matters of remuneration. I argue that there are forms of gender discrimination in the urban centres in patriarchal communities which often lead to hapless women, like Rahab of Jericho, resorting to sourcing extra money through sex work. Hence, Rahab's condition could have been a result of the effects of gender-based discrimination against women. Radu and Chekera $(2014,5)$ list the following types of gender-related segregation that women are often subjected to in Zimbabwe:

i. Financial inequality, whereby women earn a lower wage than men although they share identical professional qualifications and credentials.

ii. Glass ceiling, whereby women are prevented from competing for higher positions and climbing the professional ladder through fair and equal promotion in the workplace.

iii. Gender stereotypes, whereby definitions of femininity and masculinity influence the types of jobs that females and males can do.

iv. Pregnancy and motherhood, which are frequently used as factors upon which women are discriminated against and denied employment or promotion.

Rahab is mentioned in Hebrews 11:3 as a woman of faith and in James 2:17, 26 as a woman of good works. Greenspoon $(1985,167)$ contends that through the action of cooperating with the armies of Israel, Rahab saved both herself and her family, as well as performing a key facilitator role in Israel's crossing into the promised land. Rahab, according to Greenspoon, exemplified the kind of faith that Israelites and Christians ought to espouse in their bid to benefit from the promises of God.

The fourth woman mentioned in the Matthean genealogy is simply called by Matthew, Uriah's wife. It is not clear why Matthew chooses not to mention her name, given that 2 Samuel 11:3 and 2 Samuel 12:24 mention Bathsheba as the name of Uriah's wife, who became Solomon's mother by King David. Bathsheba became embroiled in a scandalous affair with King David, which resulted in the death of Uriah after King 
David had arranged for Uriah's demise in battle. Bathsheba became David's wife after the death of her husband. Bathsheba's second child with David, Solomon, became an erstwhile Jewish King in whose line Jesus was born. Scholars such as Berlin $(1982,73)$, Hertzberg (1964, 309), Naseri-Mutiti Naseri (2011, 12-13) and Nicol (1997, 43) have come up with views on the moral blameworthiness of Bathsheba in the story leading up to her marriage to David. Views on Bathsheba's moral indictment include the following:

i. That she had seduced King David by taking a bath in a strategic place from where the amorous king would see her (Hertzberg 1964, 309).

ii. That she had participated in the evil plot for the death of her husband (Berlin 1982, 73).

iii. That her act of arranging with prophet Nathan for her son, Solomon, to take on the reins of power after David, had revealed her original plan to beat her way into the Davidic dynasty by hook or crook (Nicol 1997, 43).

iv. That she had every opportunity to rebuff the sexual advances of King David, by which act she could have died a faithful wife to Uriah (Naseri-Mutiti Naseri 2011, 12-13).

v. That she selfishly chose to spare her own life by sacrificing Uriah's life (Naseri-Mutiti Naseri 2011, 12-13).

On the other hand, scholars like Nicol (1988, 360), Exum $(1993,120)$ and Garsiel (1993, 254) have come up with the following views that see Bathsheba as a victim of male domination and intrigue:

i. There was no way a defenceless and fragile woman like Bathsheba could resist the renowned warrior and king of David's ilk (Nicol 1988, 360).

ii. There was nothing wrong with her saving her own life and securing the future of her son (Exum 1993, 120).

iii. Everything Bathsheba did was a question of survival, safety and survival (Garsiel 1993, 254).

iv. That Bathsheba, in her own right, was intelligent and endowed with wisdom, which traits could have courted divine indulgence to make her the queen mother in the Davidic dynasty (Garsiel 1993, 254).

The story of Bathsheba can only be read from the same old script of the tough ordeal that women go through in male-dominated societies, where they are often used as sexual objects. She represents many vulnerable women who do not have the capacity to tell their own story in a predominantly patriarchal society. After she was raped by a powerful king and her husband murdered, contemptuous views started flying around suspecting her of being complicit in her own bitter experience. She is even accused of planning the death of her own husband (Exum 1993, 120). Such is always the fate of vulnerable women under patriarchal establishments. In patriarchal societies males 
define women, they think on behalf of women, define the essence of life for women and determine the destiny of women.

We conclude from the stories of Bathsheba, Ruth, Tamar and Rahab, that patrilineal societies use, abuse and silence women. However, the stories of the four women reveal graphically how God intervenes in the subjugation of the marginalised to empower them and give them an enviable destiny. The circumstances that the four women in the genealogy of Jesus passed through are similar to what women in Shona communities of Zimbabwe go through. As Zengenene and Susanti (2019, 83-93) lament, women and girls in Zimbabwe have been abused or taken for a rough ride in a number of ways, which include:

i. Denial of equal opportunities in the employment sectors.

ii. Forced early marriages for the girl child.

iii. Sexual violence against women as a form of retribution in political conflicts.

iv. Domestic violence in the form of spousal physical, psychological and emotional abuse.

v. Pressure from oppressive cultural norms that force women to sleep with their husbands, who are HIV positive, without protection.

vi. Gender stereotypes that do not allow women to rest even after spending a day at work. A woman is still expected to cook for the whole family in the evening after spending the whole day at work.

From the above, it can be concluded that there are many common traits between the Matthean and the Shona community in terms of the evils of patriarchy.

\section{Reflections on why the Four Women Were Mentioned in the Genealogy of Jesus.}

Anderson (1983, 21), arguing from a feminist theological perspective, gives Matthew kudos for challenging the domineering patriarchal system by giving women important roles in the genealogy of Jesus, as well as throughout his book. Including women in the genealogy of Jesus (against the Jewish practice of leaving out the names of women in Hebrew pedigrees) is akin to challenging the status quo. Matthew is hereby seen as straightening history but most importantly, he is on a mission to show that Jesus' salvation ground is even for both men and women. Botha (2000, 27-28) sees Matthew echoing Paul's theology in Galatians 3:28, where he says in Christ Jesus there is no slave nor free, no woman nor male but all are equal in Christ Jesus. Botha $(2003,506)$ argues that Matthew's involvement of women as key partners with men in the Jesus salvific narrative comes against the background of a strife-ridden community where a new way of viewing human history is needed. Matthew is calling upon the Jewish community to begin looking at how women can contribute to the development of human history. 
According to Naseri-Mutiti Naseri $(2011,18)$, Matthew includes the four women of foreign origins in the genealogy of the Messiah as a way of marketing and promoting Jesus as the universal saviour of all mankind. Matthew has probably lost respect for his nation's superfluously legalistic and esoteric religious tendencies; and now suggests a new approach of doing religion which is more syncretistic and accommodative of other members of the international family. Matthew is pointing to the long-forgotten, dustbinned and literally-archived people who added significant value to Jewish history as a way of awakening his fellow countrymen to the need of revisiting some of their prejudices against other races. In the same vein, Matthew is undoubtedly making a clarion call to his society to revisit its gender policies with regard to the role of women in the religious arena. Close scrutiny of the four women shows that they are all dragging supposedly checkered pasts as prostitutes (Tamar and Rahab), accursed (Ruth) and seducer (Bathsheba), but their appearance in the genealogy of Jesus presents a loud message that God is not a respecter of persons. It would also appear that Matthew is calling upon the leaders of the religious and political establishment to redefine the concepts of sin. In this vein, I agree with (Weren 1997, 288-305); the tag pinned on the four women as sexual perverts and aliens, smells of "androcentric exegesis which tags women sinners by associating them with sexuality and identifying sexuality with sin." Patriarchal backgrounds have a nefarious tendency to label women as prostitutes and sexual sinners, ignoring the fact that they themselves are partners with women in those sexual escapades and/or that the males engage in polygamous and multiple sexual unions under the protection of archaic customs.

It has also become apparent, in my assessment, that by including the four women in the pedigree of the Christ, Matthew is suggesting that the gender stereotypes that had for time immemorial sentenced women to domestic and private roles, be removed and that space is now opened for women to participate in public and political spaces as well. All four women mentioned in the genealogy exude profound wits and outstanding intellectuality in the manner in which they handled their difficult situations. Matthew is, therefore, saying to Hebrew leaders, "why not try women as frontline leaders" for a change.

In this article, it is my deep conviction that time is now opportune for the whole world (and not for Israel or Zimbabwe alone) to interrogate the efficacy and relevance of patrilineal hegemonies that cut out women from mainstream development of the communities in which they are arguably the demographic majority. I am advocating for a global agenda for women empowerment because one notices that, even in developed countries, it still attracts news headlines when a woman gets appointed to a senior position in politics. The vice president-elect of the United States of America, Senator Kamala Harris, has made news headlines as the first ever woman deputy president in the history of the United States of America. Even the United Nations has a wing called United Nations Women, which is an entity for gender equality and empowerment. The United Nations Women entity reviews ongoing progress in women empowerment and gender equality at a global level. According to the United Nations (2010) publication 
on "Achieving Gender Equality, Women's Empowerment and Strengthening Development Cooperation," the problem of gender inequality is global and not just a problem of Africa. Investment in women's education, health, social status and job opportunities is one of the United Nations' Millennium Development Goals. This means that the problem of disempowerment is a reality at a global level. In some cases, women possess the same, if not better, professional qualifications than men but socially constructed gender roles prevent women from assuming leadership roles alongside or above men. It is my strong view that Matthew could have mentioned many other women in the genealogy of Jesus. All of the 42 men mentioned in the genealogy list had wives, some of whom more than deserved mention as matriarchs of Jesus. As one reads through the genealogy, the questions that ring like an unanswered phone are: Where is Sarah, Abraham's wife? Where is Rebecca, Isaac's wife? Where is Rachel, Jacob's wife? Where is Deborah? It is high time that patrilineal societies realised that women are important partners with men in human history.

\section{Mary and the Identification of Jesus as "the Seed of the Woman"}

In this section, I challenge and question abnegation of the place of Mary and other women in the genealogy of Jesus. I begin my argument by tracing the designation of Jesus as "the seed of the woman." I query why, if Jesus is the Genesis 3:15 seed of the woman, his genealogy is crowded with 42 men against five women.

\section{Jesus the "Seed of the Woman" in early Christian Writings}

Lewis $(1991,306)$ contends that early Christian writers, Justin, Theophilus of Antioch and Iranaeus, recognised Jesus as "the seed of the woman." Ojewole $(2002,155)$ states that Justin, one of the early Christian writers, paralleled Eve and Mary in his study of "the seed of the woman." Although he acknowledged that Eve was a virgin at the time of her fall, he maintained that no child of Eve was born during her virginity. Justin stated that only Mary in her virginity was favoured by God to provide the "seed" that brought forth Jesus. Justin states concerning Jesus: "He became man by the Virgin in order that the disobedience which proceeded from the serpent might receive its destruction in the same manner in which it derived its origin." According to Justin, Virgin Eve conceived the "word of the serpent" while Virgin Mary conceived the Son of God, who himself is the Word which was with God in the beginning (John 1:1-14). Justin interpreted Genesis 3:15 to be saying that the seed of Mary would crush the head (seed) of the serpent. Irenaeus, by quoting Ephesians 1:10, propounded a doctrine of recapitulation in which the disobedience of Adam is cancelled by the obedience of Christ. Christ would crush the head of the serpent, while the head of the serpent would bruise Christ's heel on the cross. Irenaeus identified Christ as Mary's seed, which would appear to tread down the head of the enemy. Irenaeus exegeted "the seed" as messianic, connecting the seed of Genesis 3:15 with the seed of Galatians 3:19. Irenaeus taught that man struggled with the enemy until the seed appeared to crush the enemy's head and that seed had to be born of a virgin, in Mary. Both Justin and Irenaeus interpreted Isaiah 7:14 to be directly and uniquely referring to the virgin birth of Jesus Christ by Mary. The 
parthenogenesis of Christ was effected through Mary for the purpose of God preserving the purity of the Messiah.

\section{The Greek Fathers}

The Greek Fathers, whose views on "the seed of a woman" I will reflect on, are Origen, Basil the Great, Epiphanius Bishop of Salamis, Isidore Bishop of Pelusium, Gregory of Nazianzus, Cyril of Jerusalem, John Chrysostom, Anastasius of Sinai and Procopius of Gaza. The Greek Fathers' interpretation of Genesis 3:15's "seed of the woman" is dichotomous. Their interpretation pits two forces that are at war. The "head," the "heal," "the seed of the serpent" and "the seed of the woman" are dualised in a comparative analysis between God's power in Christ against the devil's powers. Origen stresses vigilance in believers to ward off the enemy's attacks, while an offensive should always be targeted at the serpent's head. While Origen generalises the seed of the woman to embrace all humanity, Basil the Great is quick to point out that it is through Christ that the church will crush the head of the serpent. Basil also states that of all women, it is only Mary who had the only single seed that brought forth Jesus. Epiphanius, Isidore and Cyril of Jerusalem interpret "the seed of the woman" as referring to Christ and that all believers are represented by Christ who crushes the enemy's head on their behalf. Chrysostom, like Anastasius, interpreted Genesis 3:15 as referring to the battle between good and evil. Gregory of Nazianzus proffered a different interpretation from the rest, in which he saw the serpent as referring to the snakes that the Israelites were going to come across in the desert and the Israelites had to prepare to contend with those snakes. Procopius of Gaza interpreted the woman to be a type of the church, while the seed was a type of all humanity in Adam.

\section{The Latin Church Fathers}

Latin Church Fathers include Tertullian, Optatus of Mileva, Cyprian, Ambrose, Augustine, Jerome, John Cassian, Gregory the Great, Isadore of Seville, Leo the Great, Abbot Rupert of Deutz and Peter Damian. Collectively, the Latin Church Fathers interpret "the seed of the woman" as referring to the battle between evil forces led by Satan and the Church of God through Christ as its head. The seed of the enemy is interpreted as the perverse works and influence of the devil, while the good works of the church are the seed of the woman. Out of the pack of Latin Church Fathers, Abbot Rupert of Deutz interpreted "the seed of the woman" as referring to Christ who came in the world through a virgin birth as the fulfilment of Isaiah 7:14.

\section{The Syrian Church Fathers}

The Syrian Church Fathers, who include Ephraim, James of Edessa, Mar Isodad of Merw, Moses Bar-Cepha, Gannat Bassame and Bar Hebraeus, have interpreted "the seed of the woman" as referring to Christ who crushed death. The bruising of the heel and the crushing of the head refers to the eternal war between good and evil, sin and righteousness. In that battle, ultimately good will prevail over evil. 


\section{The Reformation Church Fathers}

In this category of Reformation Christian Fathers, the outstanding ones are Erasmus, Luther, John Calvin and Dietrich Philips. With the exception of Erasmus, who interpreted the woman in Genesis 3:15 to be referring to the carnal part of man, the rest interpreted the woman to be referring to the Virgin Mary and "the seed of the woman" as referring to Christ who was destined to crush the head of the devil in a complete, decisive and final defeat. Most eminent in this category is Luther (1958, 192-193), who says, "what is born from Mary was conceived by the Holy Spirit and is the true Seed of Mary, just as the other promises given to Abraham and David testify, according to which Christ is called the Son of Abraham and the Son of David. Luther's view is accepted by most of contemporary scholarship that sees Christ as the seed of the woman by virtue of the virgin birth.

\section{New Testament Scholarship}

Patristic exegesis of Genesis 3:15, read with Isaiah 7:14, agrees with the majority of contemporary scholarship that Christ is "the seed of the woman" that was destined to crush the head of the ancient serpent. Some of the scholars who endorse the messianic interpretation of Genesis 3:15 include, among others, Skinner (1910, 80), Rad (1961, 90), Wifall (1974, 361-365), Hamilton (2006, 30-54) and Compton (2018, 1).

In the foregoing section, I have established that from the patristic era to the present, there is general consensus among New Testament scholars that Genesis 3:15 portends the virgin birth of Jesus as "the seed of the woman." I argue that the role that Mary, on behalf of all women played in the birth of Christ, should be recognised through strategic empowerment programmes that focus on uplifting the status of women. Mary's role on behalf of women pertains to women's place in the salvation story. A woman played a key role in the incarnation of Jesus (Galatians 4:4-5) and again, women became the first preachers of the resurrection of Jesus. The angel who addressed Mary called her "the favoured of the Lord" depicting that God's favour does not discriminate against women (Matthew 28:5-7). The Holy Bible is by and large a product of a patriarchal society with men tendentiously suppressing the role of women in the history and development of the human race. Scholars have traced the role of women in the salvation story from Eve to Mary and it has emerged that these two women stand at the two ends of the salvation story's continuum. Eve stands at the "Fall" end while Mary stands at the "Redemption" end. It would make a lot of sense for Christian doctrine to accord women their deserving status as key contributors to the Jesus story. Patriarchy should be removed from the divine order for human destiny to allow women to take their places in the public domains together with men.

\section{Findings and Recommendations}

\section{Findings}

This research has revealed the following: 
i. The inclusion of five women in the genealogy of Christ by Matthew, against an inhibitive and suppressive patrilineal background, demonstrates that the subjugation of women can be challenged from the tip of a pen.

ii. Customs that have trodden on the rights of womenfolk do not represent the mind of God on women, but are mere social constructs that can be blotted out to improve the lives of women globally.

iii. Religion has been contaminated by oppressive and inhuman patriarchal philosophies, which have nothing to do with God.

iv. Progressive and transformational exegesis is needed to highlight shortcomings in old hermeneutical traditions that militate against liberties of women as coequals with men.

v. The stigmatisation of women as sexual sinners and being inferior to men should be challenged in light of the exploits that women have scored in human history, as proven in the stories of Ruth, Tamar, Rahab, Bathsheba and Mary.

\section{Recommendations}

For future research, I recommend the following:

i. Detoxification of the scriptures through objective research that removes vain traditions of men from biblical doctrine.

ii. More research publications are needed in the area of gender and the Bible so that social transformation can begin in the church and spread throughout the whole world.

\section{Conclusion}

This article concluded that certain characteristics of the Matthean community, as reflected in the genealogy of Jesus, indicate a male-dominated society where women do not possess legal rights. Gender stereotyping benefits males, who occupy an enviable space of privilege. Levirate marriage law relegates women to the level of men's property, and inheritance and property rights are elusive to the feminine gender. Scholars question why Matthew includes five women in the genealogy list of Jesus, which is regarded as contrary to Jewish custom. From the stories of Bathsheba, Ruth, Tamar and Rahab, it is clear that patrilineal societies use, abuse and silence women; and this abuse is similar to what women in Shona communities of Zimbabwe experience. They are denied equal opportunities in the employment sectors; forced into early marriages; suffer sexual and domestic violence; are subjected to physical, psychological and emotional abuse; forced to sleep with husbands who are HIV positive; and expected to cook and clean after spending the whole day at work.

There is consensus among New Testament scholars that Genesis 3:15 portends the virgin birth of Jesus as "the seed of the woman." This article contends that the role that Mary, on behalf of all women played in the birth of Christ, should be recognised through 
strategic empowerment programmes that focus on uplifting the status of women. Patriarchy should be removed from the divine order to allow women to take their places in the public domains together with men.

\section{References}

Ademiluka, S. O. 2018. "Patriarchy and Women Abuse: Perspectives from Ancient Israel and Africa." OTE 31 (2): 339-362. https://doi.org/10.17159/2312-3621/2018/v31n2a5.

Anderson, J. C. 1983. "Matthew, Gender and Reading." Semeia 28: 3-27.

Barclay, W. 1975. The Gospel of Matthew, vol. 1. Philadelphia: Westminster Press.

Bauckham, R. 2002. Gospel Women: Studies of the Named Women in the Gospels. Grand Rapids: Wim Eerdmans.

Bauer, W., F. W. Danker, W. F Arndt, and F. W. Gingrich. 2000. A Greek-English Lexicon and the New Testament and other Early Christian Literature (BDAG). Chicago: Chicago University Press.

Benson, J. 1839. Benson's Commentary: The New Testament. New York: T. Mason and G. Lane.

Berlin, A. 1982. "Characterization in Biblical Narrative: David's Wives.” JSOT 23: 73. https://doi.org/10.1177/030908928200702304.

Botha, P. J. J. 2000. "Submission and Violence: Exploring Gender Relations in the First Century World." Neotestamentica 34 (1): 1-38.

Botha, P. J. J. 2003. “The Gospel of Matthew and Women.” Die Skriflig 37 (3): 505-532. https://doi.org/10.4102/ids.v37i3.480.

Brown, D. 1882. "The Gospel according to Matthew Commentary." In A Commentary, Critical, Practical and Explanatory on the Old and New Testaments, edited by R. Jamieson, A. R. Fausset, and D. Brown. London: G. Chapman.

Brown, R. E. 1993. The Birth of the Messiah. New York: Doubleday.

Cheater, A. P. 1986. "The Role and Position of Women in Pre-colonial and Colonial Zimbabwe.” Zambezia XIII (II): 65-79.

Compton, R. A. 2018. “The Seed of the Woman.” Table Talk Magazine, December. tabletalkmagazine.com.

Coote, R. B. 1998. "The Book of Joshua." In The New Interpreter's Bible, vol. 2, edited by B. C. Birch. Nashville TN: Abingdon Press, 596. 
Dengu-Zvobgo, K. et al. 1994. Inheritance in Zimbabwe: Law, Customs and Practices. Harare: Sapes Trust.

Ellicott, C. J. 1897. A New Testament Commentary for English Readers. London: Cassel and Co.

Erhman, B. D. 2016. The New Testament: A Historical Introduction to the early Christian Writings, 6th edition. New York: Oxford University Press.

Exum, C. J. 1993. Fragmented Women: Feminist (Sub)version of Biblical Narratives. Valley Forge: Trinity Press International.

Garsiel, M. 1993. "The Story of David and Bathsheba: A Different Approach.” CBQ 55: 254.

Greenspoon, L. J. 1985. "Rehab and Conquest." In Understanding the Word, JSOT, Sup. 37, edited by J. T. Butter. Sheffield: JSOT Press, 67-181.

Guzik, D. 2008. “The Genealogy and Birth of Jesus Christ.” Study Resources Text Commentaries: Matthew 1. Blue Letter Bible. Blueletterbible.org.

Hamilton, J. 2006. "The Seed of the Woman and the Blessing of Abraham. Genesis 3:15." The Southern Baptist Journal of Theology 10 (2): 3054.

Heffern, A. D. 1912. “The Four Women in St Matthew's Genealogy of Christ.” Journal of Biblical Literature 31 (2): 68-81.

Hertzberg, H. W. 1964. 1\&11 Samuel: A Commentary. London: SCM Press.

Kambarami, M. 2006. "Femininity, Sexuality and Culture: Patriarchy and Female Subordination in Zimbabwe.” Understanding Human Sexuality Seminar Series, Africa Regional Sexuality Resource Centre. University of Fort Hare, SA.

Landman, Christina, and Shumba Sibiziwe. 2020. "Religion and Gender Policy Implementation in Zimbabwe: Women's Access to Landownership in Gwanda District." Studia Historiae Ecclesiasticae 46 (2): 1-15.

Lewis, J. P. 1991. “The Woman’s Seed (Genesis 3:15).” JETS 34 (3): 299-319.

Lightfoot-Klein, H. 1989. An Odyssey into Female Genital Circumcision in Africa. New York: Harrington Park Press.

Luther, M. 1958. “Lectures on Genesis.” In Luther's Works. St Louis: Concordia, 192-193.

Makaudze, G. 2015. "Sex and the Female Body in Shona Society." Journal of Pan African Studies 7 (8): 140-153. 
Mwandayi, C., and S. Chirongoma. 2020. “Suspected Killer: Tamar's Plight (Genesis 38) as a Lens for Illuminating Women's Vulnerability in the Legal Codes of Shona and Israelite Societies." HTS Teologiese Studies/Theological Studies 76 (3): 10.

https://doi.org/10.4102/hts.v76i3.5893.

Meyer, H. A. W. 1887. Meyer's Commentary on the New Testament. New York: Funk and Wagnall.

Ncube, W. 1996. "Muddling in the Quicksands of Tradition and Custom and Skirting Down the Slippery Slopes of Modernity: The Reform of Marriage and Inheritance Laws in Zimbabwe." Zimbabwe Law Review 13: 1-19.

Naseri-Mutiti Naseri, C. 2011. “The Four OT Women in Matthew's Genealogy of Jesus.” Koinonia 4 (2): 1-22.

Neyrey, J. S. J. 2003. “Jesus, Gender and the Gospel of Matthew. New Testament Masculinities.” Semeia 45: 43-66.

Nicol, G. 1988. “Bathsheba, a Clever Woman?” Expository Times 99: 360. https://doi.org/10.1177/001452468809901203.

Nicol, G. 1997. "The Alleged Rape of Bathsheba: Some Observations on Ambiguity in Biblical Narrative.” JSOT 73: 43-54. https://doi.org/10.1177/030908929702207303.

Nicoll, W. R. (ed). 1897. The Expositor's Greek Testament, Vol 1-5. New York: George H. Doran Co.

Nolland, J. 1997. "The Four (Five) Women and other Annotations in Matthew's Genealogy." New Testament Studies 43 (4): 527-539. https://doi.org/10.1017/S0028688500023365.

Ojewole, A. O. 2002. "The Seed in Genesis 3:15: An Exegetical and Intertextual Study." PhD dissertation, Department of Biblical Studies, Andrews University.

Padfield, D. 2020. “The Genealogy of Christ.” Thomas Nelson Incorporated. www.padfield.com.

Parpart, J. 1995. Gender, Patriarchy and Development in Africa: The Zimbabwean Case. Women and International Development. Michigan: Michigan State University. https://doi.org/10.1093/acprof:oso/9780198290230.003.0007.

Rad, G. von. 1961. Genesis. OTL, Philadelphia: Westminster Press.

Radu, W. S. and Chekera, Y. T. 2014. "Power, Patriarchy and Gender Discrimination in Zimbabwean Newsrooms." Media Monitoring Africa, 1-26, mediamonitoringafrica.org.

Riphenburg, C. 1997. “Women’s Status and Cultural Expression: Changing Gender Relations and Structural Adjustment in Zimbabwe.” International Relations and Human Rights 44 (1): 33-49. 
Slade, D. M. 2020. "What is the Social-historical Method in the Study of Religion?" Social Historical Examination of Religious Ministry 2 (1): 1-15.

Skinner, J. 1910. Genesis. JCC. New York: Charles Scribner and Sons.

Taylor, F. 2016. What the Four Women in Jesus' Genealogy Show us about God's View on Women. Christian Today London: Christian Today International House.

Weren, W. J. C. 1997. “The Five Women in Matthew's Genealogy.” The Catholic Biblical Quarterly 59 (2): 288-305.

Wifall, W. 1974. “Genesis 3:15: A Protevangelium?” The Catholic Biblical Quarterly 36 (3): $361-365$.

Zengenene, M., and E. Susanti. 2019. "Violence against Women and Girls in Harare, Zimbabwe.” Journal of International Women Studies 20 (9): 83-93. 